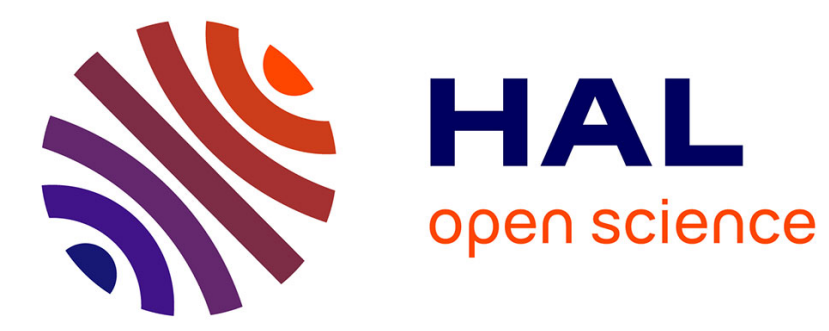

\title{
From margins to capital: The integration of spaces of artistic critique within capitalist urbanism
}

Elsa Vivant

\section{To cite this version:}

Elsa Vivant. From margins to capital: The integration of spaces of artistic critique within capitalist urbanism. Journal of Urban Affairs, 2020, pp.1-14. 10.1080/07352166.2020.1811115 . hal-02964262

\section{HAL Id: hal-02964262 \\ https: / hal-enpc.archives-ouvertes.fr/hal-02964262}

Submitted on 12 Oct 2020

HAL is a multi-disciplinary open access archive for the deposit and dissemination of scientific research documents, whether they are published or not. The documents may come from teaching and research institutions in France or abroad, or from public or private research centers.
L'archive ouverte pluridisciplinaire HAL, est destinée au dépôt et à la diffusion de documents scientifiques de niveau recherche, publiés ou non, émanant des établissements d'enseignement et de recherche français ou étrangers, des laboratoires publics ou privés. 
Vivant, Elsa. 2020 «From margins to capital: The integration of spaces of artistic critique within capitalist urbanism ». Journal of Urban Affairs, 1-14.

https://doi.org/10.1080/07352166.2020.1811115.

\title{
From margins to capital
}

\section{The integration of spaces of artistic critique within capitalist urbanism}

\author{
Elsa Vivant
}

Latts, Université Paris Est, Marne la Vallée, France

5, bd Descartes - 77454 Marne la Vallée Cedex 2 - France

Elsa.vivant@univ-paris-est.fr

Elsa Vivant is an assistant professor in urban studies. Her initial research concerns the relationship between the worlds of art and urban planning. She highlights how alternative cultural places have been progressively integrated into the dominant logics of urban production. Recently, she has been an artist in residence at the Ateliers Medicis, a new cultural venue in Paris suburbs. She has launched a new research project on the responses to the opioid crisis in the United States, in particular the ways in which conflicts over the use of public space are managed, the evolution of police practices and the controversies regarding the creation of safe consumption spaces.
Abstract
This article seeks to understand how the attitude of urban actors has changed with respect to artistic temporary use of spaces, considered here as spaces for the expression of artistic critique. I will analyse the dynamics of integrating spaces of artistic critique into city production by looking at their history in Paris, their gradual acknowledgement by institutions and, more recently, their instrumentalization. In this article, I show how capitalist urbanization has endogenized artistic critique and spaces of artistic critique 
and how this contributes to undermine the critique of capitalist urbanization by its integration into urban planning, by harnessing and misdirecting the ethical values of independence, authenticity, and freedom, and by supporting the spaces for expressing this critique. The new spirit of capitalist urbanization integrates critique to justify engagement in and to inspire actors to pursue capital accumulation, in other words, making a profit off the land. Focusing on the Parisian case and drawing on research carried out over the past twenty years, this article seeks to illuminate these ways of instrumentalizing and integrating artistic critique in view of multiple contemporary changes, in particular the injunction to an entrepreneurial self. To understand this trend, this article draws from two theoretical fields - urban studies and the sociology of art -, offering a new perspective on the interface between critical artistic practices and urban spaces.

Keyword : artistic critique; temporary use; urban planning ; Paris 


\section{From margins to capital}

\section{The integration of spaces of artistic critique within capitalist urbanism}

\section{Introduction}

Delivery pallets turned into outdoor furniture; paper lamps and flags; bars and beer taps in containers; a stage with professional sound equipment; deckchairs and young people, their feet in the sand, plastic glasses in-hand; a temporary boutique of vintage clothing set up in a warehouse; a poster advertising yoga and bicycle repair workshops: this type of setting for an evening out with friends used to bring to mind the image of an abandoned space occupied by artists critical of the sterilized and standardized contemporary places of leisure and entertainment, much like the squatter movements of the 1980s and the raves of the 1990s. Yet it is nothing of the sort. This is actually one of the numerous Parisian places whose owner has entrusted it to events organizations or companies to make use of the space while waiting for it to be transformed by property developers. Some examples include La Station Mu at Porte d'Aubervilliers, Les Grands Voisins in Paris' 14th arrondissement, the Grand Train in the 18th arrondissement, and Ground Control near the Gare de Lyon. Behind outwardly similar approaches, there are two contrasting conceptions of these temporary uses of space. Some vacant spaces have been entrusted to non-profit organizations and communities of artists who maintain close ties with spaces of artist critique. Their intention is to offer spaces where artists can work and exhibit, to propose activities for the neighbourhood and its inhabitants. Some of them provide housing for homeless people or address other needs by acting as alternative social centre. By contrast, other spaces with more media coverage are set up as temporary places for consumption, dining, and partying, designed as spaces for urban 
events offering a broader public a unique yet ephemeral experience. Their managers organize the space following principles similar to those of amusement parks (enclosure, organization of traffic, security) (Sorkin, 1992), while maintaining a bohemian appearance (made necessary by the brief duration of the occupancy).

This article seeks to understand how the attitude of urban actors (such as city government, landlord or real estate developers) has changed with respect to artistic temporary use of spaces, which have also served to express artistic critique of urban planning. As a result, temporary artistic spaces - also called "off”, "underground", or "alternative" spaces - are, in this case, considered to be spaces for the expression of artistic critique. This particular wording shows how the progressive integration of these spaces into capitalist urbanism makes sense within the more general changes in the early 21 st century. To do so, I will analyse the dynamics of integrating spaces of artistic critique into city making by looking at the history of these spaces in Paris, their gradual acknowledgement by institutions and, more recently, the instrumentalization to which they have been subject by urban actors. Even though this article is focused on Paris, similar logics of the integration and instrumentalization of spaces of artistic critique in urban renewal can be witnessed in numerous cities. From Marseille to Berlin, Copenhagen to Lausanne, spaces of artist critique have become essential components of the cultural life of cities. Integrating these spaces into cultural policies had been a prelude to using them in the service of urban policies to promote creativity (Andres and Grésillon, 2013; Colomb, 2012; Novy and Colomb, 2013; Vanolo, 2013). This trend has to be understood as a new step of the metropolitan turn in cultural policies and the emergence of metropolitan cultural governance (Saez, 2012) involving actors from worlds other than that of culture (in particular, the economic world) in the definition of objectives, means, and the implementation of local cultural policies. It stems from a 
sectoral approach that ties the fate of cities to cultural planning or creative city strategies (Evans, 2003; Pratt, 2010, 2011) in which culture is an instrument of capitalist urban production (Zukin 1991, 1995). In this context, cultural policies are assigned objectives of a different and often contradictory nature, supporting artistic creation and democratizing access to art while simultaneously acting as a driver of economic development and a factor in tourism appeal ${ }^{1}$. Whether in the case of culture-led development strategies, or of policies to support creative industries, the creative city is one of the dominant fantasies of citymakers for almost thirty years. It is founded on a few dynamic flagship operations whose ripple effects on urban development have rarely been demonstrated, and of which the negative effects have been overlooked or ignored (Atkinson and Easthope, 2009; Martin-Brelot et al., 2010; Pratt, 2010). This urbanistic fantasy leads urban actors to support cultural venues or events, with no due concern for their relevance, the conditions of their execution, or their cultural programme. Krivy argues that we have now moved beyond simple instrumentalization to the point that we are entering an era of cultural governance of urban planning conduct, which he calls “cultural governmentality” (Krivy, 2013). According to him, as opposed to being a simple planning instrument, culture is a consensual method for transforming spaces, and is becoming a governance method, in which the transformation of abandoned spaces is justified by cultural uses.

In this article, I examine the case of Paris to delve deeper into these reflections by showing how capitalist urbanism has integrated or "endogenized" (as Boltanski and Chiapello said (1999)) artistic critique or, more specifically, spaces of artistic critique. Bataille shows how the justifications and norms of the new spirit of urbanism are

\footnotetext{
${ }^{1}$ This does not mean that every cultural policy or venue plays this double bind game. Even if they contribute to the enforcement of cultural norms, many are resistant spaces of social inclusion and solidarity such as public libraries that act as safe spaces for vulnerable populations (Aptekar, 2019).
} 
shifting from civic and industrial grandeur to those of the "prospective city"2 (Bataille, 2020). Following this perspective, I show how critique of capitalist urbanism is undermined by its integration into the practices of urban planners who harness and misdirect the ethical values of independence, authenticity, and freedom, through the support of the spaces for expressing this critique. The new spirit of capitalist urbanization integrates critique to justify engagement in and to inspire actors in the pursuit of capital accumulation, in other words, making a profit off the land. By paying specific attention to spaces of artistic critique, capitalist urbanization has endogenized some of the critiques made of it regarding the disillusionment, the lack of authenticity, the standardization and the commodification of urban spaces. According to Boltanski and Chiapello, the justification grandeur of the "projective city" is the capacity to insert itself into multiple projects in order to address the temporary dimension of methods of capital accumulation. Thus, in the projective city of the new spirit of capitalist urbanization, the regime of cultural governmentality leads to the promotion of unplanned uses of spaces as a new urbanization method (Krivy, 2013). In the other spectrum of the critic, the social one, temporary management of vacancy had been presented as a way to overcome housing shortage while ensuring site security. However, as Ferreri and al. analysed (2017), such property guardianship should be understood as a face of the precarious city through the promotion of precarious housing tenure lowering tenants' rights in parallel with precarious working condition of urbanites, especially in the creative sectors. Thereby temporary uses of space convey criticism of urban planning processes by promoting spontaneous practices. Originally external to the field of urban planning, the expression of this criticism of urban planning is now central to the discourses of urban planners themselves and to property owners' and developers'

2 The "prospective city" is the concept formulated by Boltanski and Chiapello to describe the norms and values of the new spirit of capitalism (1999). 
modus operandi. I will show how the artistic critique of urbanism has become a method for implementing urban planning.

Focusing on the Parisian case and drawing on researches carried out over the past twenty years ${ }^{3}$, this article seeks to illuminate these ways of instrumentalizing and integrating artistic critique in view of multiple contemporary changes, in particular the de-autonomization of the artistic field and the injunction to the entrepreneurial self. To understand this trend, this article draws from two theoretical fields - urban studies and the sociology of art -, offering a new perspective on the interface between critical artistic practices and urban spaces. The sociology of art and artists offers a framework for analysing and understanding the realities of the work and worlds of artists that make it possible for capitalism to integrate artistic critique. Specifically, like other social worlds, artistic worlds are permeated by contradictions and power relations reflecting the diversity of social positions and the resources of various actors. In this sense they contrast with social representations of the bohemian artist, originating in 19th-century post-Revolution Parisian society (Wilson, 2003) ${ }^{4}$. Boundary spanning is the driver of aesthetic renewal, and the acknowledgement of avant-gardes involves the mobilization of a multitude of actors from the world of art and beyond. For example, the transformation of Soho (New York) demonstrates the importance of certain spaces in the professional socialization of artists. A place of artistic critique in the 1950s and 1960s, it constitutes an extreme case of overlap between art and capital in urban redevelopment, where urban history met art history and gentrification was based on the

\footnotetext{
3 This paper aims to draw a theoretical pattern based on my previous research. Since the early 2000 s, I have conducted several cases studies on temporary uses of spaces and large cultural projects. These are based on qualitative methods: archives analyses, media representation, interviews with stakeholders (especially real estate developers, city officials, artists and spaces managers). I also studied the rise of entrepreneurial self among young graduates. This paper benefits also from several researches conducted with master and PhD students. I wish to thank especially Anna Aubry, Alexandre Blein, Manon Dumont, Yoann Peres, Juliette Pinard.

${ }^{4}$ As explained later, this romantic image should not hide the entrepreneurial ethos some artists may deploy to succeed.
} 
acknowledgement of the neighbourhood's status as a hotspot of the international art market, through the recognition of new artistic forms and practices (Zukin, 1982; Bordeuil, 1994). Discourses on the creative city, establishing confusion between creation (the expression of individual subjectivity via art) and creativity (the emergence of new ideas), familiarizes individuals with logics of economic rationality and leads them to behave like entrepreneurs themselves. Artistic work has been the place to witness these changes, which have undermined the principle of the autonomy of artists underpinning artistic critique of capitalism. They are also taking place in other professional fields, namely urban planning and architecture, in which young graduates are being familiarized with the entrepreneurial ethos though business training and the rise of freelancing.

In the first section I consider the history of spaces of artistic critique and their role in urban struggles against renewal or planning projects in Paris. In the second section I show how cultural institutions' acknowledgement of these spaces and the artistic dynamics that they house is a lever for their stabilization and professionalization. This is paving the way for a third transformation, in which citymakers and real estate developers are appropriating these approaches and integrating them into their planning practices and processes. This is taking place both through the organization of the temporary occupancy of vacant properties by their owners and developers, as well as through the emergence of new young professionals in the fields of architecture, urban planning and events planning, who are developing careers managing places of artistic critique.

\section{Spaces of artistic critique of contemporary urbanization}

The city, on its walls and in its squats, is the locus of expression of the artistic critique of its own production. In the wake of the political and social movements of the 1970s, 
the emergence of spaces of artistic critique, on the fringes of the institutional and commodified worlds of art and culture, paved the way for new fields of exploration within art. New ways of conceiving the act of creation and the relationship to audiences were proposed by artist collectives who also brought a critical light on contemporary urbanization by occupying spaces, most often with no right or title. The creation of such spaces is the result of the desire of a group to promote its view of art, in a context of critical distance with respect to established art worlds. The desire to experiment with different ways of living is also one of the reasons behind the creation of spaces in which community organization, self-management, self-sufficiency, or ecological convictions are the elements of a social and political project related to the artistic undertaking (Raffin, 2002; Pruijt, 2003; Haydn and Temel, 2006; Prieur, 2015). Techno-travellers, the underground circus, avant-garde theatre, punk scenes, graffiti artists, and so on transform abandoned urban spaces, vacant lots, squats, empty warehouses, or wastelands into spaces of artistic critique. By occupying ordinary or unused spaces, artists offer a singular experience outside of the set, routine frameworks of an increasingly standardized and domesticated city (Chatterton, 2002). Spaces of artistic critique can also be space of empowerment for urban social movements through the production of artwork, cultural artefact and alternative narrative on the city (Zilberstein, 2019). Due to the particularity of its geopolitical position, Berlin was home to the emergence of these spaces of artistic critique (of capitalism and socialism alike) on both sides of the Wall (Raffin, 2002; Grésillon, 2002; Colomb, 2012; Novy and Colomb, 2013), and for many it remains the symbol of the possibility of alternative urban ways of living 5 .

\footnotetext{
${ }^{5}$ Even though, since the early 2000s, the Berlin authorities have implemented a procedure to support the temporary use of spaces for the purpose of promoting the city.
} 
In the 1980s, Paris experienced the emergence of an alternative and critical art scene through the establishment of artist squats, spaces for revolutionizing artistic practices and for expressing criticism of art worlds and, more generally, society. The Belleville neighbourhood was home to several of these, around which the alternative rock scene revolved, very close to anarchist communities and critical thinkers (Marcil, 1997; Crettiez and Sommier, 2002). This neighbourhood was also the scene of major urban struggles against urban renewal projects, in which artists in particular were involved (Gravereau, 2008). Some of these artist squats, such as La Forge, were at the heart of local network of urban activists to oppose urban renewal, evictions, and planned demolitions. In other neighbourhoods, spaces of artistic critique were the nexus of urban struggles against new development projects. The former refrigerated warehouse building (called Les Frigos) located in Paris' 13th arrondissement, abandoned in 1971 and rented to artists and artisans since 1980, was the figurehead of the resistance to the Paris Rive Gauche urban development project starting in 1991 around the new national library (the Bibliothèque Nationale de France). Upon their arrival, the occupants carried out significant work to improve the comfort and habitability of the building. Their immediate surroundings, consisting of unused railway tracks and vacant buildings, were suitable for organizing parties and illegal events. As a part of the first urban development project in 1991, the building was supposed to be demolished. The occupants of Les Frigos and urban activists promoted their alternative vision of the neighbourhood's future during artistic events and urban resistance happenings, with a view to reorienting the urban development project. Various factors (particularly the real estate crisis at the beginning of the 1990s and internal conflicts within the municipality's ruling party) contributed to the decision to maintain Les Frigos - even though the conditions of perpetuation of the site (purchased by the city) 
were a subject of bitter disputes for more than eight years (Vivant, 2010). It was also around this large-scale urban development project that graffiti underwent artification in Paris. Whereas graffiti on buildings was originally (and at times still is) considered a mark of incivility, certain urban actors (especially in this particular neighbourhood) are today commissioning the creation of street art, turning urban space into a temporary art gallery (Kullmann, 2015).

Some artists who are well known today started their activities in these spaces, using them to rehearse, produce, and build their reputation as socially and politically committed artists. Being recognized as an artist and having your work recognized as art is an achievement, especially if your stance on institutionalized methods and practices is critical. Throughout the history of art, the acknowledgement of emerging art forms by the art establishment is obtained within a singular relationship to the urban space, in particular through their expression in spaces of artistic critique. The concept of artification (Heinich and Shapiro, 2012) affords a framework for understanding how certain practices or productions are gradually acknowledged and considered as art; and, by extension, how these spaces of artistic critique have been taken into account by cultural policies. Art worlds are driven by the perpetual and systemic movement of artistic creation characterized by transgression of aesthetic codes. Establishing a new artistic paradigm and moving from the underground of the avant-garde to institutional acknowledgement involves resources, networks, and collective strategies (Becker, 1984). The artification of a practice is a sign of its legitimization, its autonomization, and its aestheticization. It is the result of the intervention of many actors, particularly a circle of followers that gradually expands to include the general public via the establishment of a critical device and entry into institutional art spaces. 
For young artists, spaces of artistic critique as places of artistic creation are spaces for socializing and building a professional identity and legitimacy as an artist. At times, however, these loci of expression of artistic critique of contemporary urbanization suffer from negative exposure in the media, where their controversial image is supported by reports on deviance and environmental disturbance (noise), including tragic events such as overdose deaths. Yet spaces of artistic and social critique do not necessarily imply the refusal of external norms and rules; on the contrary, the survival and longevity of these places depends on the occupants behaving as good squatters and good neighbours (Coutant, 2000). Some of them set up activities for the local populations, such as neighbourhood parties, flea markets, workshops for amateurs, etc. These actions are ways of demonstrating their goodwill towards the authorities, of making themselves accepted by local residents, of being acknowledged by the media, and therefore of obtaining a wider variety of support. Pacifying neighbourhood relations is a prior condition to any attempt to discuss and negotiate with the authorities, because there is no hope of remaining there without the support of local residents. Normalizing occupancy by regulating or even banishing certain behaviours (such as the use of illegal drugs) makes it acceptable and paves the way for institutional recognition of these spaces and their activities (Vivant, 2010). For example, the endurance of Christiana in Copenhagen is related to the ability of its activists to implement self-management rules, to respect certain requirements of the public authorities (such as paying taxes), and to open their spaces to the public (following a logic of the non-privatization of spaces) (Vanolo, 2013). This is one of the few spaces of artistic critique that has been able to survive for several decades, not without tensions, contradictions and concessions through which the occupants have unintentionally contributed to the urban changes that they denounced (Thörn, 2012) 


\section{The professionalization of spaces of artistic critique}

Since the late 1990s, spaces of artistic critique have become targets of public policy, with regard to both culture and urban issues. The French Ministry of Culture has conducted a study of these places - some of which convey a critical discourse on cultural institutions, and specifically the ministry itself - to identify their features and difficulties. The study highlights their importance in local artistic dynamics and in the emergence of new artists, and makes proposals to help perpetuate them and support their activities (Lextrait, 2001). This institutional interest is both put forward by artists in their negotiations with local authorities, to defend and secure their occupation, and acts as a source of inspiration for local communities seeking models to design new cultural places ${ }^{6}$.

For some artists, criticism of capitalist urban planning is the core argument of their claim, as artists, for workspace. For example, certain squatters deliberately choose central and symbolic locations that offer better visibility not only in urban space but also in the art world. Their main demand, faced with the threat of eviction and the lack of affordable space, concerns the perpetuity of occupancy that will enable them to make the long and uncertain work of creation possible ${ }^{7}$. Media exposure of the risk of eviction and constant postponement raise the public's awareness around their problems and demands, while presenting an act of urban subversion. While artists denounce scandalous increases in real estate prices to justify squatting, their central urban location and media visibility also allow them to develop a reputation and to join the art world through a presence in neighbourhoods with an important symbolic value and a large

${ }^{6}$ The creation of the 104 , a public cultural institution of the City of Paris, explicitly drew inspiration from these experiences.

${ }^{7}$ Similar claims for workspaces for artists in the gentrification era has been identified in the analysis of Toronto newspapers (Bain and March, 2019). 
concentration of art galleries. In other words, for them, squatting is not an end in itself but rather a means to practice an artistic profession ${ }^{8}$. By demanding the right to a work place, through the act of squatting, they have put the issue of the lack of spaces for artists on the political agenda (Vivant, 2010). This instrumental mobilization of artistic criticism of urban planning has laid the foundations for new relations between the public authorities, occupants, and owners, while triggering a gradual dis-autonomization of spaces of artistic critique through their professionalization.

Starting in 2001 with the arrival of a new municipal government (a left-wing coalition), the City of Paris' policy to support artistic creation favoured public domain occupancy agreements with artist collectives for the use of its own temporarily vacant buildings. It drew inspiration from the situation in Holland, where urban squatter social movements were gradually institutionalized through processes to legalize occupations (Pruijt, 2003). The interest of various cultural institutions, along with the new forms of support offered by local government, has definitely had an impact on artistic spaces and their organization. While occupying a place has always involved certain imperatives (like carrying out restoration work), entering into the system of agreements and subsidies creates new obligations and responsibilities. It is an opportunity to stabilize and consolidate the occupancy of a space and acts as a lever in the professionalization of its occupants by requiring them to master the tasks necessary to operate the place (managing an annual budget, training on security regulations, etc.). There is thus a shift away from the amateurism of the first squats, which goes hand-in-hand with new occupancy rules as the city pays more attention to the activities carried out at these sites.

8 The emergence of strategic squatters has not replaced radical and politicized squatter movements, which are more discreet and receive less media attention. The endogenisation of critique does not wipe it but makes it less audible especially when it express through illegal migrants encampments. 
By doing so, the system of agreements and subsidies comes to resemble an instrument of political action that forces art collectives to professionalise (Aguilera, 2012).

The path followed by the Alpha artist collective (a pseudonym to maintain its anonymity), which went from squatting to contract with public bodies to manage art venue, clearly illustrates this shift (Dumont, Vivant, 2016). These young artists met at the beginning of the 2000s at a Parisian squat. Intent on setting up their own project, they successively occupied several spaces with no rights or title. Their first steps towards legality were initiated by an owner who preferred to negotiate an amicable departure, to avoid the delays of legal proceedings. By respecting the terms of the agreement, the artists demonstrated their good will and were later able to benefit from temporary occupancy agreements for properties owned by the City of Paris, eventually occupying multiple sites simultaneously. With the skills acquired from these experiences, they submitted a bid and were awarded a public service outsourcing contract for the management of an artist residence owned by the City of Paris. This last step marks the completion of a trajectory of professionalization that took place through tests constituting the stages of a career (Becker, 1963) as an operator of an artistic space: starting as a practice considered deviant, they acquired skills on-the-fly and developed a professional demeanour ${ }^{9}$. They became a reliable intermediary trusted by the public authorities and owners to negotiate and stabilize occupancy since negotiation is an acquired skill and demonstration of professionalism is a condition of success.

The variety of professional skills required to manage an artistic space resonates with the new conditions of artistic work (McRobbie, 2002). In current contemporary neoliberal governmentality (Foucault, 2004), individuals are steered, by more or less explicit injunctions, to think like an enterprise and direct their actions around the

${ }^{9}$ This professionalization often takes place through hiring staff to manage and maintain the site. 
rational calculation of cost and efficiency. Artists at work are a common representative case of this new entrepreneurial self, because faced with the uncertainty of success and profitability, the project-based organization of artistic production goes hand-in-hand with insecurity, the intermittent nature of the activity, and the instability of income, which moreover is often limited. These conditions are supposedly made acceptable by the idealization of artistic work, according to which the low level of income is offset by the chosen, non-routine, and fulfilling nature of the work (Menger, 2002; McRobbie, 2002; Neff et al., 2005; Storey et al., 2005; Gill and Pratt, 2008; Ross, 2008). Precarious working conditions have now their twin in the housing market through the promotion of non-standard tenure, such as property guardianship, as an adventurous living. Both are means to normalise precarious and insecure working and living conditions (Ferreri et al, 2017, Vivant, 2013). The romantic representation of the artist whose calling justifies involvement in an artistic career, despite the uncertainty of success (Bourdieu, 1975; Heinich, 2005), is accompanied by the representation of works as the unique and irreplaceable production of an inspired individual expressing her or himself by departing from both aesthetic and social conventions within an autonomous artistic field. The artist subverts the established order and offers something new, which she or he will have to convince people to accept, or will even have to establish as a new norm, with the transgression of aesthetic codes constituting a component of the recognition and definition of the work's value. An undertaking to subvert the established order and a demand for autonomy are therefore components of artistic critique of capitalism. The association of the ideas of the artist and the enterprise is also found in two historicized conceptions of the entrepreneur. The bohemian artist is reminiscent of the chivalrous figure of the entrepreneur who launches into an adventurous enterprise, without worrying about the risks, in a search for self-realization (Vérin, 1982). In another sense, 
visual artists are Schumpeterian entrepreneurs insofar as they put a new element on the market (an aesthetic novelty) and must find allies (gallery owners, peers, critics, collectors) for this innovation to be accepted (Moulin, 1992).

The professionalization of spaces of artistic critique reveals the ambiguity of artists with respect to money and the market, between demands for the autonomy of the artistic field, freedom of creation and art as a vocation, and the importance of market logic and the reproduction of social inequalities in access to a career. Worlds of art and creative milieus are battlegrounds in which success takes place through recognition (by peers or the public) and in which inequalities in success and income are highly publicized (in the form of prizes and awards), thus endorsing competition between individuals. For example, the discursive repertoires of art school graduates with regards to money tend to give more credit to the grandeur of the market city (with commercial success being a factor in the validation of the artistic practice) rather than those of the inspired city (according to a principle of the autonomy of art) (Taylor and Littleton, $2008)^{10}$. Moreover, in creative enterprises, the necessity of economic survival contributes to a certain acceptance of management logic; artistic critique is undermined and is only expressed when the core of the activity - artistic creation - is endangered by managerial logic (Chiapello, 1998).

This professionalization is met with little opposition so long as it does not compromise the projects and activities of the space and its occupants. The implementation of selection criteria for the projects to host, the introduction of market logics, skyrocketing rental prices, and participation in management fees are sources of tension and disagreement. In other words, not allowing everybody to carry out their projects is more of a concern than changes in the management of occupancy. This

${ }^{10}$ Some contemporary artists explicitly think of themselves as entrepreneurs specifically seeking profit. 
balance between management logic and artistic project logic is negotiated in terms of possibilities and constraints, but may fail and lead to dissent. For instance, some artists left Alpha collective because they disapproved the agreements made with the City. Faced with requirements, proposals, or opportunities from the public authorities and owners, not every artist collective adopts the same attitude, between adaptation and resistance. Whereas spaces of artistic critique were created by militants and artists occupying vacant spaces, with or without the authorization of the owner, opportunistically and without long-term planning, the provision of sites by owners forces occupants to structure themselves, adopt a legal form, and formalize a project and a budget that the owner will assess, evaluate, and even compare to others. In certain cases only one of several candidates may be chosen. In other words, these procedures implement a rationale of competition for access to space between artist collectives, even though they share the same critical stance on such conditions. Cultural governmentality thus compels actors with a critical view of urban planning to adapt or to run the risk of being marginalized by the arrival of new actors.

\section{Integrating artistic critique at the risk of its dissolution}

In Paris, as in other cities, over the past few years, the establishment of spaces of artistic critique has transitioned from a logic of laissez faire to one of commissioning in the context of urban projects, while the need for work space for artists has been reframed into a contribution to the economic dynamism of the city. Beyond contracts to manage property vacancies, planners and landowners are taking advantage of temporary uses of space as a way of managing the timing of urban development projects: to secure, open up to the public, and valorise them (Vivant, 2009; Andres and Grésillon, 2013). More than a mere guardianship, landowners are making vacant spaces available through calls for project proposals of new uses, which force operators into competition with one 
another or with commercial project brokers. Authorizing occupations (whether artistic or not) during the transition period of spaces is a way of preventing squatting and other illegal practices (e.g. the sale of illegal drugs), changing the image of the sites and neighbourhoods in question, and in particular prefiguring their future. The occupants (or rather the temporary occupation managers) propose uses presented as new (open-air bar, brewery, coworking). But they face, in the implementation, with comfort and safety standards, constraining the development of organised and commodified temporary uses of space. For instance, because of the impossible compliance with housing standards, most of them do not offer temporary housing. At the same time, certain actors of artistic critique have appropriated the discourse on creativity and inter-urban competition, making use of it in their negotiations. While denouncing the failures of urban neoliberalism, some squatter artists use current discourses on creativity as a driver of city development to justify and legitimize their practices (Uitermark, 2004). This weakening of the critique is reminiscent of the concept of cultural industry. This concept has been created to critically analyse the standardization resulting from the application of industrial reproduction techniques to cultural creation, and to highlight the contradictions between this practice and the essence of art as the singular expression of an artist. The critical perspective has been replaced by socio-economic analysis of cultural industries aimed at understanding how art and culture have been integrated into capitalist commodification, in other words, the transformation of a use value into a market value, and how these activities have been structured as an economic sector.

This dissolution of artistic critique makes it possible for it to be integrated into the new spirit of capitalist urban planning. The establishment and perpetuation of spaces of artistic critique enable the encounter between different interests. For example, the founder of the $6 \mathrm{~B}$, an office building rented from the early 2010 s to artists and creative 
enterprises in a Parisian suburb, sought from the outset to root this facility in the city. By organizing outdoor events in the summer, the $6 \mathrm{~B}$ became involved in breathing life into the newly built neighbourhood, in association with the local authorities, which saw it as the materialization of its project for a territory self-labelled "culture and creation" (Aubry et al, 2015). The owner and site developer supported these events through corporate patronage. In 2019, another French real estate developer created an endowment to support so-called "transient urbanism" projects on its properties. Using corporate patronage to support spaces of artistic critique reflects the growing role of philanthropy in French cultural life following changes in legislation and taxation as well as the creation of new legal instruments ${ }^{11}$. While the State and local authorities used to finance cultural action through various public policies, the use of patronage to finance public facilities and the creation of philanthropic cultural institutions constitutes a major turning point. In a context of austerity, cultural institutions are competing for access to resources (either public funding or charitable donations) and their management model is shifting towards an entrepreneurial logic (Vivant, 2011). Investment in philanthropy is a way of redefining the rules of the game of power by establishing the criteria for allocating funding and establishing good practices, while boasting of the altruistic virtues of the donation ( $\mathrm{Wu}, 2002)$.

Transient urbanism has the appearances of spaces of artistic critique but aimed to activate vacant land. Thus, presenting as philanthropic an intervention at a place that aims to activate it has its ambiguities. Using the verb to activate [French: activer] to describe the role of activities temporarily organized at empty spaces is recent, and it is worthwhile considering its meanings to understand its implications. To activate is to make something that was previously latent active. For chemists, activation is the

11 Since the 2003 laws on philanthropy and the 2008 law creating endowments thru tax incentives. 
operation whereby the properties of a substance are increased in order to enhance its efficacy (such as by making it radioactive). To activate is to accelerate and amplify a process. In French, the same semantic family also contains the term asset [actif], referring to the goods composing an entity's wealth. It is the opposite of a passive subject [passif], which is the element that undergoes the effects of an action, and according to a different meaning, the term to refer to the debts and expenses that encumber an entity's wealth. To activate can be replaced with other verbs, such as to animate [animer] (to entice to action), which makes more reference to activities aiming to strengthen social ties; or to occupy [occuper] (to take possession of or be the object of attention of), which more explicitly expresses power relations and political movements whose mechanism of action is occupation (of a public space or a factory). Therefore, using activate rather than animate or occupy conveys the capitalist logics implied by the temporary uses that this term describes and which are relevant here. The purpose is to enhance the properties of a vacant space to increase its urban development potential and real estate income in order to increase the owner's wealth - despite the fact that in some of the cases studied, the uses and actors involved claim to have ties to spaces of artistic critique. The defining features of the projective city, which are networks and connectivity, justify the temporary dimension of accumulation reflected in temporary methods for transforming urban spaces as a way of "activating" them.

Just as critical art works have been integrated into the art world through an artification process, so too are spaces of artistic critique being integrated into the world of urban planning through the involvement of certain actors working to change the boundaries and renew the conventions of the world of urban planning. In so doing they are integrating certain criticism of urban planning into urban planning practices. For example, "transient urbanism" experiments, inspired by spaces of artistic critique, call 
into question the traditional practices of urban planning. These practices, which delegate the use of a space awaiting its transformation in order to prefigure future uses, renew the project-based urbanism peculiar to the era of urban entrepreneurialism in a context of uncertainty (Harvey, 1989; Ascher, 2001) ${ }^{12}$. The appropriation of these methods by landowners or real estate developers also meets the challenges of these organizations in terms of management strategies. For example, organizing the management and temporary occupation of vacant railway spaces can be understood in terms of the evolution of the strategy of the SNCF Group (the French national railway company), with respect to real estate management, urban project management, and the oversight of internal change in the company (Pinard, forthcoming).

A dual process is at work: the professionalization and institutionalization of spaces of artistic critique; and the aspiration of some planning and real estate actors to experiment with new methods (Pinard, Morteau, forthcoming). Concretely, new operators with roots in planning or real estate are positioning themselves as professionals specialized in the temporary management of vacant spaces, acting as intermediaries between owners and users (such as Plateau Urbain or La belle friche created by young graduates in planning and architecture). The change in the uses and management methods of temporary spaces is based on the personal and professional paths of the people orchestrating them, some of whom are from artistic communities, and others from the world of urban planning. Temporary occupation addresses a personal need for space for the first, and the identification of a new professional position as an intermediary for the second. New professions are appearing, such as a group of young freelancers specialized in seeking out sponsorship and creating business

\footnotetext{
${ }^{12}$ The endogenization of artistic critique of urban planning by urban planning can also be found in the new forms of interrelation between local authorities and real estate companies in the form of calls for so-called "innovative" projects, such as Réinventez Paris [Reinvent Paris], in which certain operators of spaces of artistic critique are participating.
} 
models for artist squats ${ }^{13}$. This does not occurs without contradictions. For instance, one of the most famous temporary occupation (Grands Voisins) hosted a shelter for migrants, claiming for the right to the city (in reference with Henri Lefebvre works). At the same time, its manager, a cooperative corporation, promoted its methods and references in front of real estate developers at an international fair. While these new professionals deny it, they tend to win the trust of owners (with whom they share a professional habitus) and become referees of "good temporary management", with artists and militants being required to agree to their regulations, practices... and prices. They create a market for temporary occupancy when vacant spaces are rented whereas they used to be squatted. Managing spaces of artistic critique has therefore become an economic activity, subject to competition by property owners and financial sponsors. Seen as an alternative to the dominant model, the spaces of artistic critique are becoming an ordinary practice that traditional urban planning actors (planners, owners, developers) are appropriating. These new generations of transient urbanism professionals, who have been graduating since the end of the 2000s, have been familiarized with entrepreneurship and the business spirit by specific training for students (Chambard, 2013) and by the implementation of new independent professional activity regimes (the "auto-entrepreneur" self-employment regime in France). This independent status is used by companies as an instrument for making the organization of work more flexible, reducing salaries and associated expenses, and outsourcing human resources management. The development of self-employment is turning out to be an instrument for learning the behavioural norms that make workers the entrepreneurs of the self (Hesmondhalgh and Baker, 2010; Abdelnour, 2017; Vivant,

\footnotetext{
${ }^{13}$ One of them is also a freelance journalist writing about these spaces. Yet, as Bain and March emphasis, "journalists have the power to mediate between urban actors to set agenda for urban growth" (2019: 179). The multipositionality of these new professionals should raise concerns about the potential for conflicts of interest.
} 
2016). By integrating artistic critique into managerial discourses (Boltanski, Chiapello 1999), entrepreneurial engagement at work, such as in the case of artists, is also being deployed in the social world. These changes enable us to understand how spaces of artistic critique are promoted today by professionals and entrepreneurs who take the risk of offering new activities in a budding market, to the detriment of more militant approaches.

\section{Conclusion}

As sociology of art has analysed, the romanticised image of the artist goes in hand with an entrepreneurial self, whether it is to propose a new piece of art on the market or to organise its production in regard with economic constraints. The transgression of codes and the expression of an artistic critique are the drivers of the avant-garde in art and its recognition Likewise, the recognition of transgressive uses of spaces (i.e. spaces of artistic critique) as space for art creation by local authorities paves the way to a new form of cultural governmentality in urban planning. This comes first with the professionalization of the management of the spaces in respect with budget, safety, neighbourly rules. Seen as an alternative to the dominant model, temporary use of space is commodified and becomes a usual practice for urban planning actors. They call for projects and thus implement a rationale of competition. Like artistic work is modelling the conditions of contemporary workers (Menger 2002), artistic uses of spaces is now seen as a new norm and method to figure their future uses. Managing spaces of artistic critique has become an economic activity, subject to competition. As well as non-monetary rewards (pleasure, self-expression, social recognition) make precarious working conditions acceptable in creative sectors, precarious occupancy and temporary management are presented as mean to experiment and shelter new uses and users to change the way cities are made. This narrative hides the risks and effects of this 
insecure tenancy for occupants contributing to the rise of the precarious city (Ferreri et $a l, 2017)$. Inspired by spaces of artistic critique, temporary uses of space are now implemented by professionals from other fields (entertainment, architecture, planning), reminding the way the creative narrative had expand the model and image of creation beyond the boundaries of art production. So, temporary uses of space inspired by spaces of artistic critique are losing their transgressive potential with respect to the ordinary practices of urban planning. Cultural governmentality thus compels actors with a critical view of urban planning to adapt.

The path of the institutionalization of spaces of artistic critique of urban planning is not the only example of the endogenization of artistic critique. The collaboration of artists with urban planning actors in the more or less institutional processes of creative place making (Redaelli, 2016; Arab et al. 2016), while considered to be mechanisms of creativity and the renewal of urban planning practices (Boren and Young, 2013), can also can contribute to extinguishing artistic critique of urban planning. Similarly, tactical or do-it-yourself urban planning practices are an everyday method for transforming urban spaces today (Mould, 2014). These socially-engaged experiments, deployed on the fringes of institutions, are becoming a part of the repertoire of citymakers' actions. Combining urban studies and the sociology of art offers a new framework for understanding how artistic critique is integrated into capitalist urbanization. The myth of the romantic artist engaged in a precarious career in order to follow his or her vocation is the basis of the ideal of autonomy presented by the artistic critique of capitalism. This then has become the justification for the rise of independent work. This illustrates the ambiguous relationship between artistic critique and money, which makes the integration of this critique within monetary value creation possible. These ambiguities are found in the integration of spaces of artistic critique into 
the logics underpinning urban projects. These places are a new form of expressing power over urban space, in which mechanisms - presented as being authentic (Zukin, 2010) - of the appropriation of the space actually pertain to relations of domination over it, via the socially situated and economically organized expression of an artistic critique of urban planning.

\section{References}

Abdelnour, S. (2017) Moi, petite entreprise. Les auto-entrepreneurs, de l'utopie à la réalité. Presses Universitaires de France, Paris.

Aguilera, T. (2012) Gouverner les illégalismes. Les politiques urbaines face aux squats à Paris. Gouvernement et Action Publique 3, 101-24.

Andres, L. and Grésillon, B. (2013) Cultural brownfields in European cities: a new mainstream object for cultural and urban policies. International Journal of Cultural Policy 19.1.

Aptekar, S. (2019) The Public Library as Resistive Space in the Neoliberal City. City \& Community 18.4, 1203-19.

Arab, N., Ozdirlik, B. and Vivant, E. (2016) Expérimenter l'intervention artistique en urbanisme. Presses Universitaires de Rennes, Rennes.

Ascher, F. (2001) Les nouveaux principes de l'urbanisme. La fin des villes n'est pas à l'ordre du jour. Editions de l'Aube, La Tour d'Aigues.

Atkinson, R. and Easthope, H. (2009) The Consequences of the Creative Class: the Pursuit of Creativity Strategies in Australia's Cities. International Journal of Urban and Regional Research 33.1, 64-79. 
Aubry, A., Blein, A., Vivant, E. (2015) The promotion of creative industries as a tool for urban planning:The case of the Territoire de la Culture et de la Création in Paris Region International Journal of Cultural Policy 21.2, 121-38.

Bain, A. L. and March, L. (2019) Urban Redevelopment, Cultural Philanthropy and the Commodification of Artistic Authenticity in Toronto. City \& Community 18.1, 173-94.

Bataille, N. (2020) Experts et consultants au service de l'action publique locale. Une approche pragmatique du travail de l'ingénierie privée, Thèse de doctorat en aménagement de l'espace et urbanisme. Université de Tours, Tours.

Becker, H. S. (1963) Outsider. Etudes de sociologie de la déviance. AM Métailié, Paris.

Becker, H. S. (1984) Art Worlds. University of California Press, Berkeley.

Boltanski, L. and Chiapello, E. (1999) Le nouvel esprit du capitalisme. Gallimard, Paris. Bordeuil, J.-S. (1994) Soho, ou comment le 'village' devint planétaire. Villes en Parallèle 20-21, 145-81.

Boren, T. and Young, C. (2013) Getting Creative with the 'Creative City'? Towards New Perspectives on Creativity in Urban Policy. International Journal of Urban and Regional Research 37.5, 1799-1815.

Bourdieu, P. (1975) L'invention de la vie d'artiste. Actes de la recherche en sciences sociales 2, 67-94.

Chambard, O. (2013) La promotion de l'entrepreneuriat dans l'enseignement supérieur. Les enjeux d'une création lexicale. Mots. Les langages du politique 102, 10319.

Chatterton, P. (2002) "Squatting is Still Legal, Necessary and Free": A Brief Intervention in the Corporate City. Antipode 34.1, 1-7. 
Chiapello, E. (1998) Artistes Versus Managers. Le management culturel face à la critique artiste. Métailié, Paris.

Colomb, C. (2012) Pushing the Urban Frontier: Temporary Uses of Space, City Marketing and the Creative City Discourse in 2000s Berlin. Journal of Urban Affairs 34.2, 131-52.

Coutant, I. (2000) Politique du squat. La Dispute, Paris.

Crettiez, X. and Sommier, I. eds. (2002) La France rebelle. Tous les foyers, mouvements et acteurs de la contestation. Editions Michalon, Paris.

Dumont, M. Vivant, E. (2016) Du squat au marché public: trajectoire de professionnalisation des opérateurs de lieux artistiques off Réseaux, 200, $181-208$.

Evans, G. (2003) Hard-Branding the Cultural City - from Prado to Prada. International Journal of Urban and Regional Research 27.2, 417-40.

Ferreri, M., Dawson, G., Vasudevan, A. (2017) Living precariously: property guardianship and the flexible city Transactions of the Institute of British Geographers 42, 246-59.

Foucault, M. (2004) La Naissance de la biopolitique. Cours au Collège de France (1978-1979). Ehess - Gallimard - Seuil, Paris.

Gill, R. and Pratt, A. (2008) In the Social Factory? Immaterial Labour, Precariousness and Cultural Work. Theory, Culture and Society 25.7-8, 1-30.

Gravereau, S. (2008) Artistes de Belleville : entre mondes de l'art et territoires urbains, Thèse de doctorat, Sociology. Ecole des Hautes Etudes en Sciences Sociales, Paris.

Grésillon, B. (2002) Berlin, Métropole culturelle. Belin, collection Mappemonde, Paris. 
Harvey, D. (1989) From Managerialism to Entrepreneurialism: The Transformation in Urban Governance in Late Capitalism. Geografiska Annaler. Series B, Human Geography 71.1, 3-17.

Haydn, F. and Temel, R. eds. (2006) Temporary Urban Spaces. Concepts for the Use of City Spaces. Birkhäuser, Basel.

Heinich, N. (2005) L'élite artiste: Excellence et singularité en régime démocratique. Gallimard, Paris.

Heinich, N. and Shapiro, R. eds. (2012) De l'artification. Enquêtes sur le passage à l'art. Editions de 1'Ecole des Hautes Etudes en Sciences Sociales, Paris.

Hesmondhalgh, D. and Baker, S. (2010) "A very complicated version of freedom": Conditions and experiences of creative labour in three cultural industries. Poetics 38.1, 4-20.

Krivy, M. (2013) Don't Plan! The Use of the Notion of Culture in Transforming Obsolete Industrial Space. International Journal of Urban and Regional Research 37.5, 1724-46.

Kullmann, C. (2015) De l'exposition de la Tour Paris 13 au concept de musée à ciel ouvert: le street art au service du projet urbain? Téoros 34.

Lextrait, F. (2001) Friches, laboratoires, fabriques, squats, projets pluridisciplinaires...: une nouvelle époque de l'action culturelle. Paris: Ministère de la Culture, http://www.culture.gouv.fr/culture/actualites/ 15 January 2002.

Marcil, E. (1997) Bérurier Noir. Conte cruel de la jeunesse. Camion Blanc. Folklore de la zone mondiale, Paris.

Martin-Brelot, H., Grossetti, M., Eckert, D., Gritsai, O. and Kovacs, Z. (2010) The Spatial Mobility of the 'Creative Class': a European Perspective. International Journal of Urban and Regional Research 34.4, 854-70. 
McRobbie, A. (2002) Clubs to Companies: Notes on the Decline of Political Culture in Speeded Up Creative Worlds. Cultural Studies 16.4, 516-31.

Menger, P.-M. (2002) Portrait de l'artiste en travailleur. Métamorphoses $d u$ capitalisme. La République des idées, Seuil, Paris.

Mould, O. (2014) Tactical Urbanism: The New Vernacular of the Creative City. Geography Compass 8.8, 529-39.

Moulin, R. (1992) L'artiste, l'institution et le marché. Flammarion, Paris.

Neff, G., Wissinger, E. and Zukin, S. (2005) Entrepreneurial Labor among Cultural Producers: 'Cool' Jobs in 'Hot' Industries. Social Semiotics 15.3, 307-34.

Novy, J. and Colomb, C. (2013) Struggling for the Right to the (Creative) City in Berlin and Hamburg. New Urban Social Movements, New 'Spaces of Hope'? International Journal of Urban and Regional Research 37.5, 1816-38.

Pinard, J, Morteau, H. (forthcoming) Professionnels de l'occuaption temporaire, nouveaux acteurs de la fabrique de la ville ? De l'émergence d'un métier au renouvellement des méthodes en urbanisme, Revue internationale d'urbanisme

Pinard, J. (forthcoming) From experience to expertise, structuring transient urbanism as a new urban and real estate strategy. The case of the French National Railway Compagny (SNCF). In Andres, L. (ed.), Transforming Cities through Temporary Urbanism: A Comparative International Overview. Springer.

Pratt, A. (2010) Creative Cities: Tensions Within and Between Social, Cultural and Econcomic Developpement. A Critical Reading of the UK Experience. City, Culture and Society 1.1, 13-20.

Pratt, A. (2011) The Cultural Contradictions of the Creative City. City, Culture and Society 2.3, 123-30.

Prieur, V. (2015) Revendications des squats d'artistes et institutions. Marges 20, 74-95. 
Pruijt, H. (2003) Is the Institutionalization of Urban Movements Inevitable? A Comparison of the Opportunities for Sustained Squatting in New York City and Amsterdam. International Journal of Urban and Regional Research 27.1, 13357.

Raffin, F. (2002) Les ritournelles de la culture. De la crtitique sociale à la participation citoyenne, entre mobilités et ancrages urbains, Thèse de doctorat en Sociologie. Université de Perpignan, Ecole Doctorale Sciences Humaines et Sociales, Perpignan.

Redaelli, E. (2016) Creative placemaking and the NEA: unpacking a multi-level governance. Policy Studies 37.4, 387-402.

Ross, A. (2008) The New Geography of Work. Power to the Precarious? Theory, Culture and Society 25.7-8, 31-49.

Saez, G. (2012) Le tournant métropolitain des politiques culturelles. In Saez, G. and J.P. Saez (eds.), Les Nouveaux Enjeux Des Politiques Culturelles. Dynamiques Européennes. La Decouverte. Serie ‘Territoires du politiques’, Paris.

Sorkin, M. ed. (1992) Variations on a Theme Park. The New American City and the End of Public Space. The Noonday Press, New York.

Storey, J., Salaman, G., Platman, K. (2005) Living with enterprise in an enterprise economy: Freelance and contract workers in the media. Human Relations 58.8, 1033-54.

Taylor, S. and Littleton, K. (2008) Art Work or Money: Conflicts in the Construction of a Creative Identity. The Sociological Review 56.2, 275-92.

Thörn, H. (2012) In Between Social Engineering and Gentrification: Urban Restructuring, Social Movements, and the Place Politics of Open Space. Journal of Urban Affairs 34.2, 153-68. 
Uitermark, J. (2004) The Co-optation of Squatters in Amsterdam and the Emergence of a Movement Meritocraty: A Critical Reply to Pruijt. International Journal of Urban and Regional Research 28.3, 687-98.

Vanolo, A. (2013) Alternative Capitalism and Creative Economy: the Case of Christiana. International Journal of Urban and Regional Research 37.5, 178598.

Vérin, H. (1982) Entrepreneurs, entreprise. Histoire d'une idée. Classiques Garniers, collection Histoire des techniques (edition de 2011), Paris.

Vivant, E. (2009) How Underground Culture is Changing Paris. Urban Research and Practices 2.1, 36-52.

Vivant, E. (2010) The (re)Making of Paris as a Bohemian Place? Progress in Planning $74.3,107-52$.

Vivant, E. (2011) Who Brands Whom? The Role of Local Authorities in the Branching of Art Museums Town Planning Review 82.1, 99-115.

Vivant, E. (2013) Creatives in the City. Urban contradictions of the creative city. City, Culture and Society 4.2, 57-63.

Vivant, E. (2016) Rejection, Adoption or Conversion. The Three Ways of Being a Young Graduate Auto-Entrepreneur. Work Organisation, Labour \& Globalisation 10, The precariousness of knowledge workers (Part 1): hybridisation, self-employment and subjectification, 68-83.

Wilson, E. (2003) Bohemians. The Glamorous Outcasts. Tauris Parke Paperbacks, New York.

Wu, C.-T. (2002) Privatising Culture. Corporate Art Intervention since the 1980s. Verso, London. 
Zilberstein, S. (2019) Space Making as Artist Practice: The Relationship between Grassroots Art Organizations and the Political Economy of Urban Development. City \& Community $18.4,1142-61$

Zukin, S. (1982) Loft Living. Culture and Capital in Urban Change. Rutger's University Press, New Brunswick.

Zukin, S. (1991) Landscapes of Power. From Detroit to Disney World. University of California Press, Berkeley.

Zukin, S. (1995) The Cultures of Cities. Blackwell Publisher, Cambridge.

Zukin, S. (2010) Naked City. The death and life of authentic urban places. Oxford University Press, New York. 